\begin{tabular}{|c|c|}
\hline \multirow{3}{*}{ 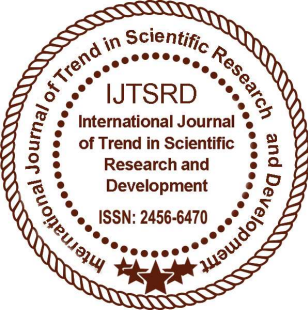 } & $\begin{array}{l}\text { International Journal of Trend in Scientific } \\
\text { Research and Development (IJTSRD) }\end{array}$ \\
\hline & International Open Access Journal \\
\hline & ISSN No: 2456 - 6470 | www.ijtsrd.com | Volume - 2 | Issue - 4 \\
\hline
\end{tabular}

\title{
Design and Fabrication of Solar Grass Cutter to Increase Cutting Space Using Scotch Yoke Mechanism
}

\author{
K Hema Mahesh Babu, J Suresh
}

Asst. Professor, Department of Mechanical Engineering, Siddharth Institute of Engineering \& Technology, Puttur, Chittoor, Andhra Pradesh, India

\begin{abstract}
Solar energy is the light that comes from sun and is the earth's most abundant energy source. Everyday sun radiates enormous amounts of energy into space and with the development of technology such as the solar cell, we are able to collect this energy and convert it into usable electricity. The Indian farmers have been using large machineries in cultivation with high cost of processing. In order to save energy, control pollution, reduce fuel consumption, increase the cutting space, easy to operate this grass cutter have made. This Grass cutter most familiar in the low cost, compact in size, eco-friendly to the nature. It enables to provide more cutting space comparing with previous designs.
\end{abstract}

Keywords: Grass cutter, scotch yoke mechanism, solar energy, increased cutting space, reciprocating motion mechanism, photo-voltaic principle, Renewable energy

\section{INTRODUCTION:}

\section{Introduction}

Solar energy is radiant energy that is produced by sun. The sun radiates more energy in one second than people have used since the beginning of time. The hydrogen atom in the suns core combine to helium and generate energy inn process called nuclear fusion. Since most renewable energy is ultimately "solar energy" that directly collected from sun light. Energy released by sun as electromagnetic waves. This energy reaching the earth's atmosphere consists of about $8 \%$ UV radiation, $46 \%$ visible light, $46 \%$ infrared radiations.

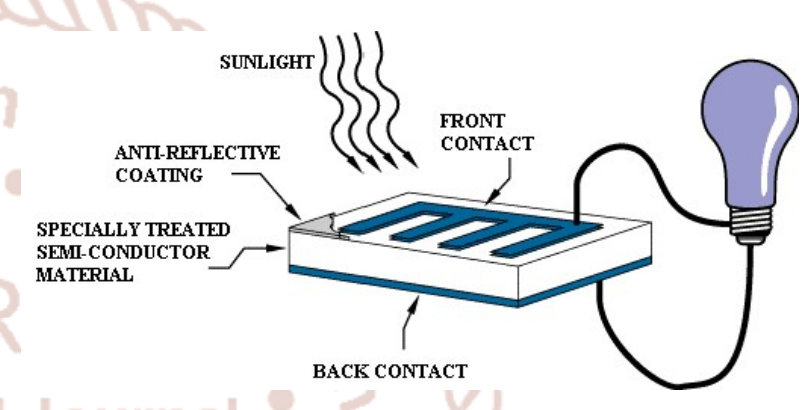

Sun light can be directly converted into electricity via a photovoltaic or solar cell using the photo electric effect. In simple terms, the photoelectric effect occurs when light is shone onto matter causing a small current flow through it. The light provides energy to the electrons in atoms of the matter enabling them to move around to create a current. A solar panel composed of three thin, float layers made up of silicone negatively charged particles called charge. The middle, or junction layer, is insulator between the n-type and p-type silicon. Sunlight is made up of stream of energy particles called photons. When these photons strike the top layer of the solar cell they are observed and initiate a current. This current occurs when the photons strike the n-type silicon atom and knock the electrically charged away from their "parent" atoms and attracted to the positively charged protons in p-type silicon layer of solar cell and are passed along wires that connect to consuming item, such as battery, where they are de-energized and flow back into the solar cell ready to be re-energized again. Single solar cells are linked together in panels they can produce enough electricity to power a whole building. 
International Journal of Trend in Scientific Research and Development (IJTSRD) ISSN: 2456-6470

1.1 Utilization of solar energy in the world:

\begin{tabular}{|l|l|l|l|l|}
\hline $\begin{array}{c}\text { Hydro } \\
\text { Energy }\end{array}$ & $\begin{array}{c}\text { Wind } \\
\text { Energy }\end{array}$ & $\begin{array}{c}\text { Solar } \\
\text { Energy }\end{array}$ & $\begin{array}{c}\text { Geo } \\
\text { Thermal } \\
\text { Energy }\end{array}$ & $\begin{array}{l}\text { World } \\
\text { Rank }\end{array}$ \\
\hline Canada & Germany & Japan & Us & 1 \\
\hline Us & Us & Germany & Philippines & 2 \\
\hline Brazil & Spain & Italy & Us & 3 \\
\hline China & Denmark & Mexico & India & 4 \\
\hline Russia & India & Indonesia & Australia & 5 \\
\hline
\end{tabular}

\subsection{Advantages of Solar Energy}

$>$ Solar energy is a clean and renewable energy source.

$>$ Once a solar panel is installed, solar energy can be produced free of charge.

$>$ Solar energy causes no pollution.

$>$ Very little maintenance is needed to keep solar cells running.

$>$ In the long term, there can be a high return on investment due to the amount of free energy a solar panel can produce

\section{Components and description}

\subsection{Components}

The main components of the solar powered grass cutter are,

2.1.1 Solar panels

2.1.2 Batteries

2.1.3 DC motor

2.1.4 Scotch yoke mechanism

2.1.5 Blades

\subsubsection{Solar Panels}

A solar cell works on the principle of photo-voltaic principle, the photo-voltaic solar energy conversion is one of the most attractive non-conventional energy sources of proven reliability from the micro to the Megawatt level.

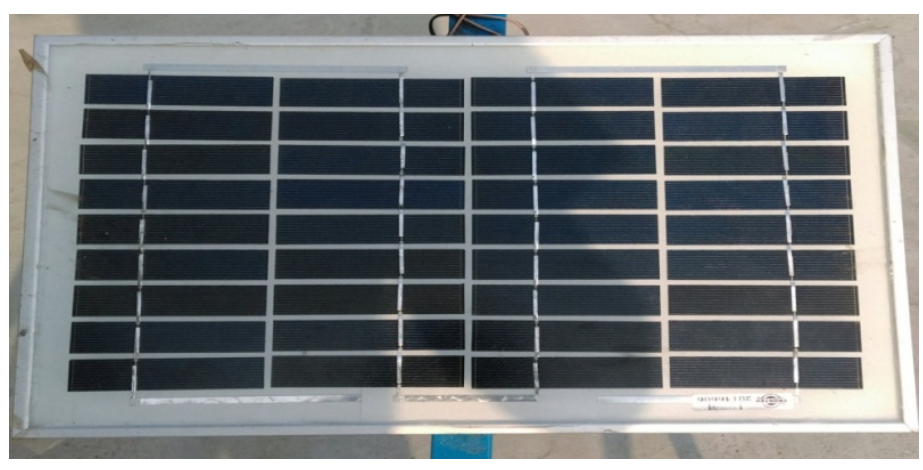

In actual usage, solar cells are interconnected in a certain series and parallel combinations to from modules. These modules are hermetically sealed for production against corrosion, moisture, pollution and weathering combination of suitable modules constitutes on array.

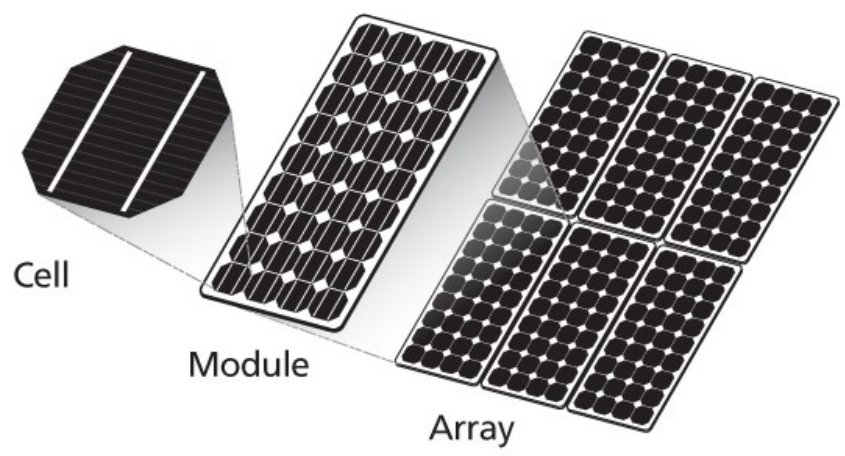

Solar panel Specifications:

8 W Panels:

$>\quad$ Array size : $355 \times 255 \times 25 \mathrm{~mm}$

$>\quad$ Maximum Power $: 8 \mathrm{~W}$

$>\quad$ Maximum Voltage : 18V

$>\quad$ Maximum Current : $0.55 \mathrm{~A}$

$>\quad$ Open circuit voltage $: 21.6 \mathrm{v}$

\subsubsection{Battery}

Where high values of load current are necessary, the lead-acid cell is the type most commonly used. The electrolyte is a dilute solution of sulfuric acid

$\left(\mathrm{H}_{2} \mathrm{SO}_{4}\right)$. In the application of battery power to start the engine in an auto mobile, for example, the load current to the starter motor is typically 200 to 400A. One cell has a nominal output of $2.1 \mathrm{~V}$, but lead-acid cells are often used in a series combination of three for a $6-\mathrm{V}$ battery and six for a $12-\mathrm{V}$ battery.

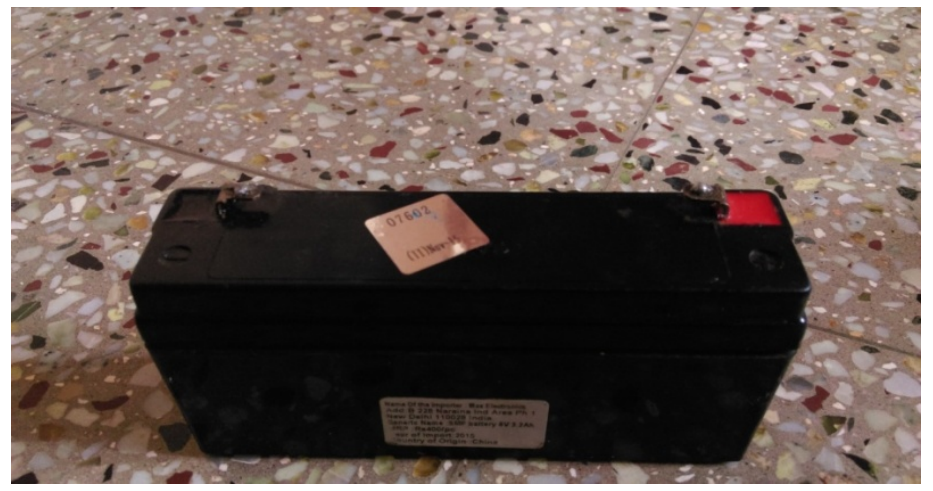

\subsubsection{Motor}

An electric motor is a machine which converts electrical energy to mechanical energy. Its action is based on the principle that when a current-carrying conductor is placed in a magnetic field, it experiences a magnetic force whose direction is given by Fleming's left hand rule. When a motor is in 
operation, it develops torque. This torque can produce mechanical rotation. DC motors are also like generators classified into shunt wound or series wound or compound wound motors.

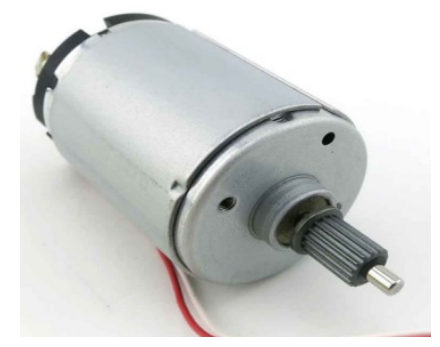

\subsubsection{Scotch yoke mechanism}

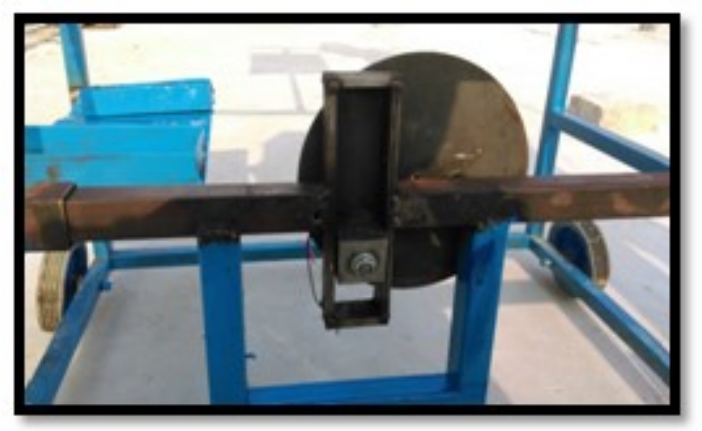

The Scotch yoke (also known as slotted link mechanism) is a reciprocating motion mechanism, converting the linear motion of a slider into rotational motion or vice versa. The piston or other reciprocating part is directly coupled to a sliding yoke with a slot that engages a pin on the rotating part. The shape of the motion of the piston is a pure sin wave over time given a constant rotational speed.

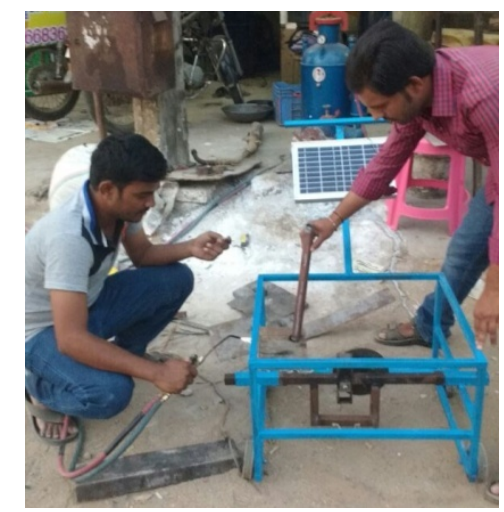

Fig. Mechanism frame welding

\subsubsection{Blades}

In this grass cutter to cut grass we have used that made by aluminum place and then made it as blade by cutting teeth and making sharp edges by grinding.

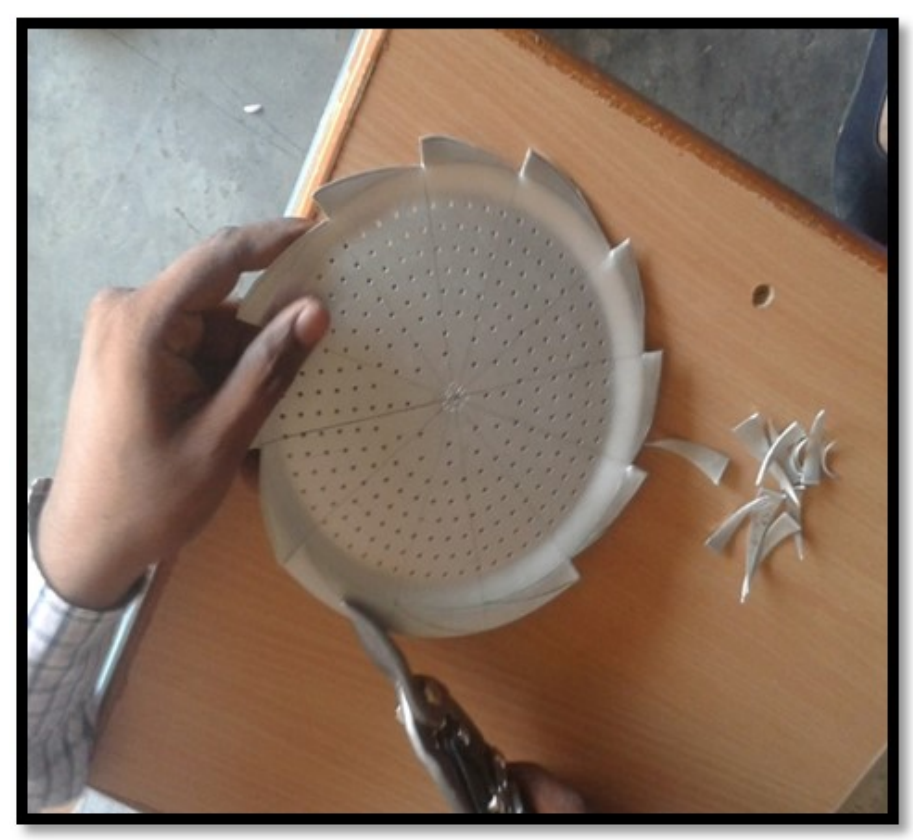

Fig. Teeth cutting and grinding of Blade

\section{Working of Grass Cutter}

As it has panels mounted in a particular arrangement at an angle of 45 degrees in such a way that it can receive solar radiation with high intensity easily from the sun. These solar panels convert solar energy into electrical energy as studied earlier. Now this electrical energy is stored in batteries by using a solar charger. The main function of the solar charger is to increase the current from the panels while batteries are charging; it also disconnects the solar panels from the battery.

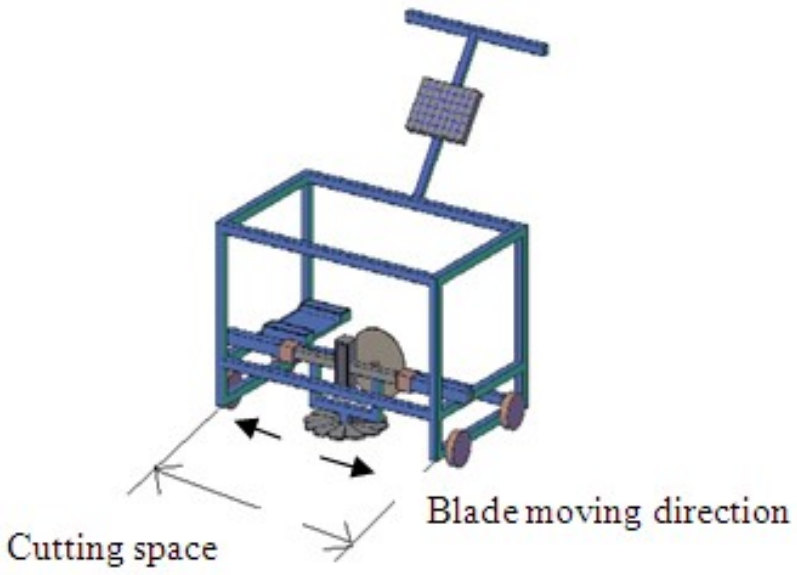

When they are fully charged and also connect to the panels when the charging in batteries is low. The motor is connected to the batteries through connecting wires .Between these two mechanical circuit breaker switch is provided. It starts and stops the working of the motor. From this motor, the power transmits to the mechanism and this makes the blade to slide on the fixed blade and this makes to cut the grass. 
4. Calculations

\section{Torque and Power}

Power, $(\mathrm{P})=\mathrm{V} \times \mathrm{I}=12 \times 7.5=90 \mathrm{~W}$

Speed, $(\mathrm{N})=3000 \mathrm{rpm}$

We know, Power $(\mathrm{P})=\frac{2 \pi N T}{60}$

$$
\begin{aligned}
& 90=\frac{2 \times \pi \times 3000 \times T}{60} \\
& \therefore \text { Torque, }(T)=0.286 \mathrm{~N}-\mathrm{m}
\end{aligned}
$$

\section{W PANEL}

Charging voltage $\quad=14.2 \mathrm{~V}$

Open circuit voltage $\quad=18 \mathrm{v}$

Full short circuit current $=0.45(\max )$

\subsection{Ah BATTERY}

Time for chargin $=$

minimum power storage of battery $\times$ current

Full short circuit current

$$
\begin{aligned}
& =\frac{0.50 \times 7.5}{0.45} \\
& =8 \text { hours }
\end{aligned}
$$

\section{Conclusion}

This grass cutter is more suitable for a common man as it is having much more advantages i.e, no fuel cost, no pollution and no fuel residue, less wear and tear because of less number of moving components and this can be operated by using solar energy. As we are nearer to Equator, the solar energy (non-conventional energy) is vastly available, so it is easy to charge the battery and is also pollution free. But the initial investments of the solar powered grass cutter are high. At present in order to curtail global warming and ozone depletion, the Government of India is offering subsidy for the solar equipments. The industries are producing these components in mass productions, so the cost of the system may come down. So in future it is expected to run all equipments by using solar energy. This system is having facility of charging the batteries while the solar powered grass cutter is in motion. So it is much more suitable for grass cutting continuously.

\section{References}

1. Bainer R, Kepner RA, Berger EL (1978) Principles of farm machinery, $3^{\text {rd }}$ edn. Willey, New York.

2. Bautista E, Regalado JS, Juliano A, Ishihara S, Monobe H, and Ramos J, Molinawe L (2005) The PhilRice-JICA rotary rice reaper: redesigning a technology for Filipino farmers and manufacturers. Rice is life: scientific perspectives for the 21 st century 7: 229-232.

3. Chakraverty A, Mujumdar AS, VijayaRaghavan GS,Ramaswamy HS (2003) Handbook of postharvest technology cereals, Fruits, Vegetables, Tea and Spices. Marcel Dekker Inc, p 883.

4. Ganesh CB, Gunner KH (2007) Low cost mechanical aid for rice harvesting. J Appl Sci. $7(23): 315-320$

5. Thiruchelvam T; Nimal D A D; Upali S (2007). Com-parison of quality and yield of copra processed in CRI improved kiln drying and sun drying. Journal of Food Engineering, 78,14461451 